\title{
Experimental Effects of a Lightweight Mussel Dredge on Benthic Fauna in a Eutrophic MPA
}

Bromhall, Katrina; Dinesen, Grete E.; McLaverty, Ciarán; Eigaard, Ole R.; Petersen, Jens Kjerulf; Saurel, Camille

Published in:

Journal of Shellfish Research

Link to article, DOI:

$10.2983 / 035.040 .0300$

Publication date:

2021

Document Version

Peer reviewed version

Link back to DTU Orbit

Citation (APA):

Bromhall, K., Dinesen, G. E., McLaverty, C., Eigaard, O. R., Petersen, J. K., \& Saurel, C. (2021). Experimental Effects of a Lightweight Mussel Dredge on Benthic Fauna in a Eutrophic MPA. Journal of Shellfish Research, 39(2), 1-13. https://doi.org/10.2983/035.040.0300

\section{General rights}

Copyright and moral rights for the publications made accessible in the public portal are retained by the authors and/or other copyright owners and it is a condition of accessing publications that users recognise and abide by the legal requirements associated with these rights.

- Users may download and print one copy of any publication from the public portal for the purpose of private study or research.

- You may not further distribute the material or use it for any profit-making activity or commercial gain

- You may freely distribute the URL identifying the publication in the public portal 


\title{
Experimental effects of a lightweight mussel dredge on benthic fauna in a eutrophic MPA
}

\author{
Katrina Bromhall, ${ }^{1 *}$ Grete E. Dinesen, ${ }^{1}$ Ciarán McLaverty, ${ }^{1}$ Ole R. Eigaard, ${ }^{1}$ Jens Kjerulf \\ Petersen $^{2}$ and Camille Saurel ${ }^{2}$
}

\author{
${ }^{1}$ DTU Aqua, National Institute of Aquatic Resources, Denmark; ${ }^{2}$ Danish Shellfish Centre, Øroddevej \\ 80, 7900 Nykфbing Mors, Denmark
}

*Corresponding author. E-mail: krmb@aqua.dtu.dk

J. of Shellfish Research, 40(3):519-531 (2022). https://doi.org/10.2983/035.040.0309

\begin{abstract}
Dredging for wild mussels Mytilus edulis Linnaeus, 1758 takes place in marine protected areas (Natura 2000 sites) in Denmark. The fishery is strictly regulated to limit the impact of dredging to the benthic environment, and requires the use of modified lightweight mussel dredges. Nevertheless, the depletion of the benthic macrofauna associated with M. edulis beds after impact from such dredges is yet to be quantified. Here, dredging is shown to result in a significant decline in the density, species richness, and biological traits directly in the dredge track but no significant impact on the community composition. Species richness remained significantly affected 4 mo post dredging, although the positive trend after 4 mo may signal recovery. An effect of dredging was also detected in areas adjacent (approximately $5 \mathrm{~m}$ ) to the dredge tracks, but needs further investigation to understand this impact. The results provide an estimate of benthic macrofaunal depletion in the dredge track as well as of the short-term recovery, which may be of use in the management of the fishery. Finally, it is suggested that species richness may be a more sensitive indicator than density in a eutrophic and species-poor system.
\end{abstract}

KEY WORDS: Before-After-Control-Impact (BACI), biological traits, bivalve fishery, ecosystem based fisheries management, fisheries effects, mussel, Mytilus edulis

\section{Introduction}

Globally, 15 million tons of bivalve molluscs are produced each year for human consumption, of which $11 \%$ are exploited from wild stocks (Wijsman et al. 2019). In Europe, scallops, blue mussels, and cockles dominate wild bivalve landings (FAO 2020). Exploited bivalves live in or on the seabed, thus the fishing gear used for harvesting comes into direct contact with the seabed. The interaction causes a disturbance to the benthic habitat and the associated fauna (Kaiser et al. 2006). Bivalve harvesting is typically undertaken using dredges, which are relatively small, compact, and heavy towed gear that can include a bar or teeth to penetrate the surface sediments (Eigaard et al. 2016). Most research regarding the impacts of bivalve dredging to benthos stems from studies conducted on scallop fisheries (Thrush et al. 1995, Currie \& Parry 1999, Hall-Spencer \& Moore 2000, LeBlanc et al. 2015, Sciberras et al. 2016). Scallop dredging is deemed by some to be one of the more damaging fishing gears, although a large body of literature shows there to be a variable response of benthic communities to scallop dredging (Kaiser et al. 2006, Sciberras et al. 2018). Far less is known about other forms of bivalve dredging, some of which occur in dynamic, shallow systems, prone to high levels of natural (e.g., waves and storms) and anthropogenic (e.g., eutrophication) disturbance.

The Limfjord in Northern Denmark is a shallow microtidal-tidal system in which blue mussels (Mytilus edulis, Linnaeus, 1758) are dredged from wild stocks. In 2012, new legislation initiated the switch from a heavier traditional Dutch dredge to a modified lightweight dredge (hereafter termed 
light dredge) in part to mitigate the damage to the seabed from dredging. Although the light dredge has been shown to cause significantly less physical impact to the seabed by reducing sediment retention and drag resistance (Frandsen et al. 2015), the direct impact to the benthic macrofauna from the light dredge is less well understood. A comparative (gradient) study found a decline in macrofaunal biomass and a change in species composition correlated with light-dredging intensity, although were highly dependent on local environmental conditions (McLaverty et al. 2020). In addition, experimental trawling using a 1:2 scaled version of the Dutch dredge resulted in $2-5 \mathrm{~cm}$ furrows in the sediment, and a short-term decline in species richness (Dolmer et al. 2001). Thus, to meet the objectives of an Ecosystems Approach to Fisheries Management, a direct assessment of the effect of the light dredge to seabed macrofauna is of particular interest to fisheries managers.

An obstacle to an Ecosystems Approach to Fisheries Management in the Danish blue mussel fishery is the fact that the areas where $M$. edulis fisheries occur are also characterized by remarkably high levels of eutrophication associated with intense agricultural runoff (Ærtebjerg et al. 2003). Although this nutrient enrichment has promoted blue mussel growth and high mussel biomass (Dolmer 1998), eutrophication also causes periodic oxygen depletion in some areas of the Limfjord. Eutrophication has a strong and predictable structuring influence on benthic communities (Pearson \& Rosenberg 1978). Under high nutrient enrichment, communities tend to be dominated by opportunistic fauna that can tolerate low oxygen and rapidly recolonize areas when mass mortality occurs. While the effects of eutrophication on benthos is relatively well understood, there is a paucity of research regarding the effects of trawling in organically enriched areas.

Fishing grounds for M. edulis in Denmark overlap with a number of Natura 2000 sites designated for their conservation value under the European Union (EU) Habitats Directive (European Union 1992). To ensure sustainable fisheries in these areas, strict regulations of the mussel fishery were instated in 2012 (Foreign Ministry of Denmark 2019). This introduced the use of mandatory black box devices on fishing vessels operating in Natura 2000 areas (Nielsen et al. 2021). The black box data are used for several purposes, including to limit the footprint of dredging activity $(\leq 15 \%$ of seabed) within Natura 2000 sites. The spatial footprint of dredging activity is calculated using the black box data and the gear dimension. Estimating gear-based fisheries footprints in such a manner is common practice in the EU (Eigaard et al. 2017, ICES 2019). Nevertheless, this method does not currently consider the indirect effects of dredging, for example, on the area immediately adjacent to the dredge track (within meters), where there is potential for organisms to be exposed to sedimentation from dredging activity (Pastor et al. 2020), possibly leading to an underestimation of the impact footprint.

The aim of this study was to investigate the direct (dredge track) and indirect (adjacent to the dredge track) effects of the light dredge on $M$. edulis-associated macrofauna in a highly eutrophic system. The study represents the first experimental dredging study on benthic macrofauna using this type of fishing gear. Using black box data, an area of seabed unfished for $4 \mathrm{y}$ before the study was identified. At this location, a Before-After-Control-Impact (BACI) experiment was conducted. To sample the direct and indirect effects of mussel dredging accurately, a scuba diver collected macrofaunal samples from within the dredge track, immediately adjacent to the dredge track (up to 5 $\mathrm{m}$ distance), and in a control site. Samples were also collected 4 mo after dredging to assess shortterm recovery.

\section{Materials and Methods}

\section{Study Area}

Løgstør Broad is a large shallow basin situated in the north east of the Limfjord, Denmark (Fig. 1). The mean water depth is $7.2 \mathrm{~m}$ and salinity is 27.3 (Josefson \& Hansen 2004). Seabed conditions in Løgstør are categorized as sandy or sandy mud substrates. Patches of M. edulis form on top of the 
substrate and create a seabed with a mosaic of bare sand and complex biogenic structure. Annual water temperature fluctuate between $0^{\circ} \mathrm{C}$ and $22^{\circ} \mathrm{C}$ (Hoffmann \& Dolmer 2000) and water movement is predominantly driven by westerly winds (Dolmer \& Frandsen 2002). Low levels of wind and high temperatures during summer can lead to thermal stratification. In the Løgstør Broad, a Natura 2000 site with surrounding coastal area covers an area of $441 \mathrm{~km}^{2}$. Active environmental monitoring of the site started in 2004 and management commenced in 2011, in compliance with the Habitats Directive.

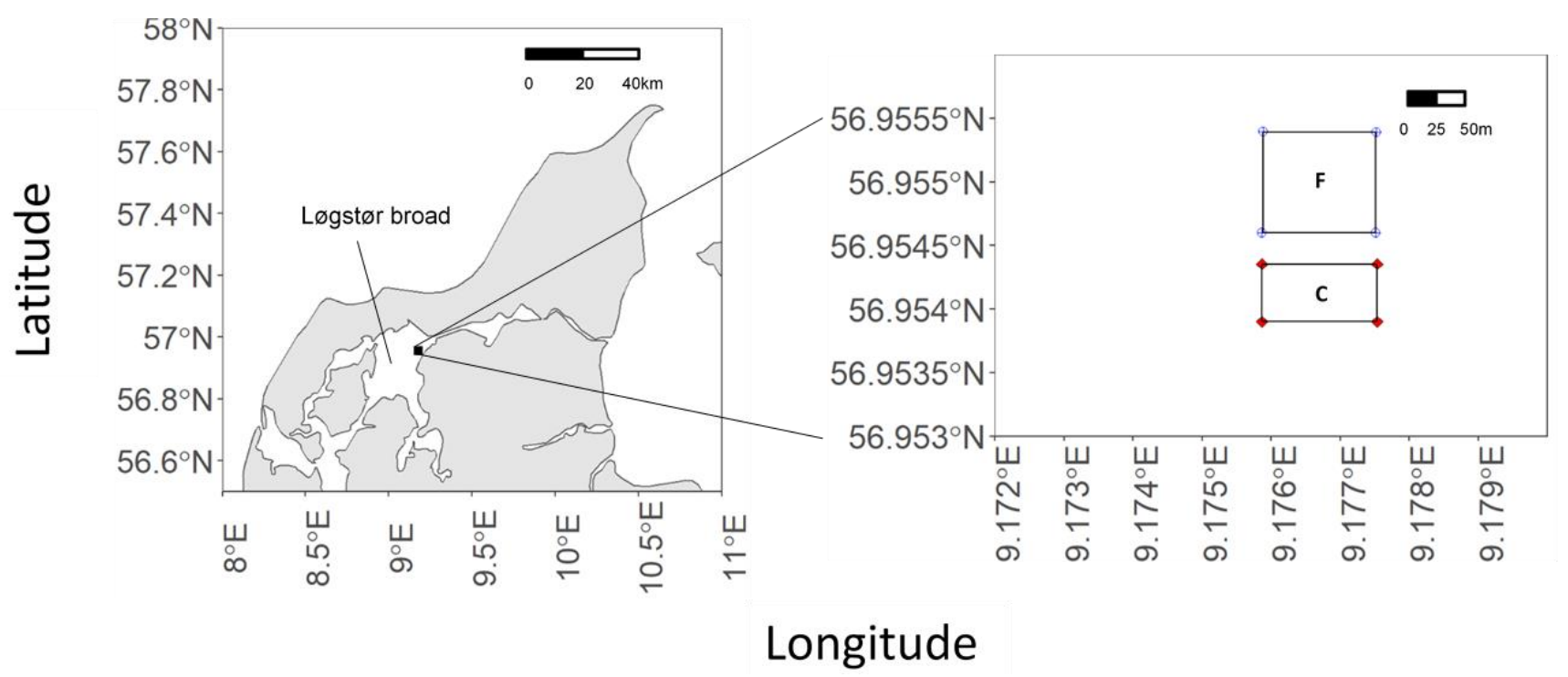

Figure 1. Map of the study site in Løgstør Broad, Limfjord, Denmark, and location of respective fished (F) and control (C) sites.

\section{Experimental Design}

To quantify the effect of the light dredge, a BACI experimental design was conducted. A BACI uses a factorial design to determine an impact based on a significant interaction between "Time" (before, after) and "Treatment" (control, impact) (Green 1979). A significant interaction occurs when the change in time (i.e., the slope between before and after experimental disturbance) differs in the control and impact treatments. Black box data were used to locate an area where dredging had been absent for multiple years, and validated that the study sites had not been dredged for $4 \mathrm{y}$ prior to the experiment (Fig. 1). Due to the scarcity of large mussel beds in areas unfished for more than $3 \mathrm{y}$, the study was constrained to including only one control and one impact site. Although the criticism of such designs are recognized (Underwood 1992), the viewpoint of Stewart-Oaten and Bence (2001) was taken. The control sites are not typical experimental controls (as conducted in laboratory experiments), but instead highly correlated covariates and serve to represent the treatment site in an undisturbed condition (Stewart-Oaten \& Bence 2001). Thus, the efforts made to ensure that the control site represented the impact site, allowed for the examination of the experimental disturbance.

The fished site was experimentally dredged using the commercial light dredge, whereas the control site remained unfished for the duration of the study period. The boundary of the fished site marks the southernmost dredge track based on black box data and the minimum measured distance to the control site was $30 \mathrm{~m}$. As the predominant bottom currents were northwards, the control site was located south of the fished site to reduce the possibility that sediment plumes from the dredging activity affected the control site. 


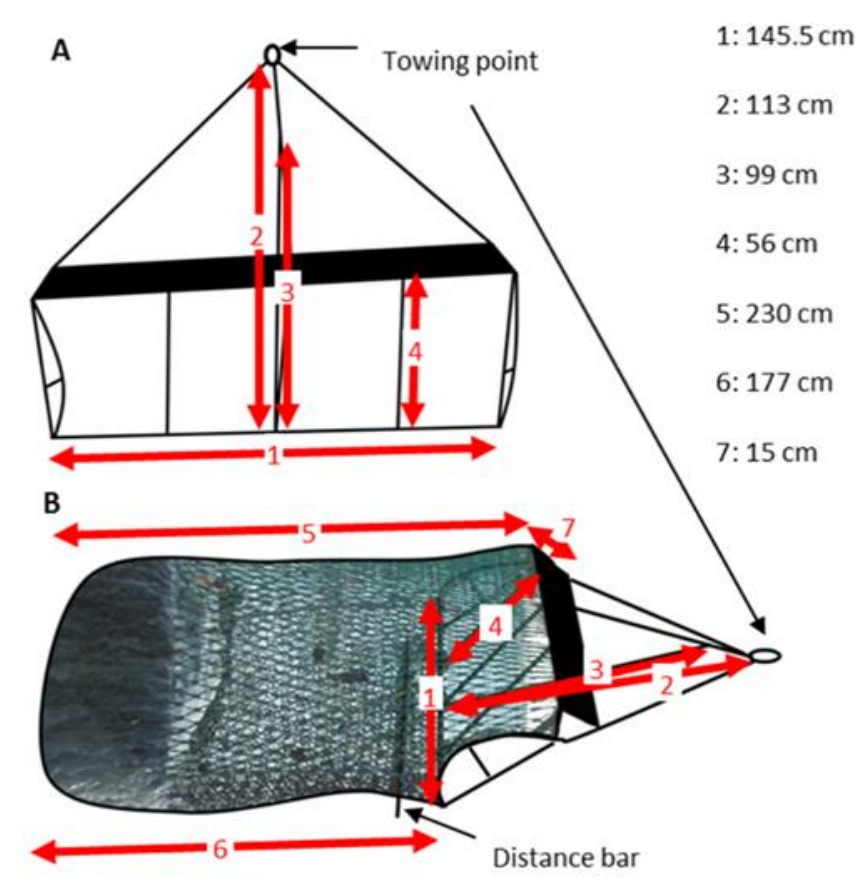

Figure 2. The dimensions of the light dredge seen from (A) the front and (B) the side. Reproduced from Frandsen et al. 2015.

Experimental dredging took place in the fished site on the 15th and 22nd of May 2017. The gear was as shown in Figure 2, with each dredge weighing $123.4 \mathrm{~kg}$ (Frandsen et al. 2015). A licensed fishing vessel conducted the experimental dredging rigged with two light dredges on each side (four in total). The catch efficiency of the dredge is variable, depending on the mussel bed structure, percentage cover, and substratum. In some instance, catch efficiency has been recorded to be as low as 50\%, meaning that after dredging, some mussel patches remain in the dredge track (Dolmer et al. 1999). Macrofaunal samples were collected from mussel patches at three time intervals: before dredging on May 10, 2017 ("before"), the day after dredging on May 23, 2017 ("after"), and 4 mo after dredging on September 20, 2017 (“4-mo after"). In the fished site, samples taken after dredging were collected from inside and outside of the gear path. Samples taken inside the gear path are referred to as "dredge track," whereas those outside (approximately $5 \mathrm{~m}$ from the dredge track) are referred to as "adjacent to the track," shown in Figure 3. As the recovery of seabed habitats after trawling is thought to occur through immigration from the surrounding area and through local recruitment (Lambert et al. 2017), samples were also taken 4 mo after dredging to assess recovery from dredging. 


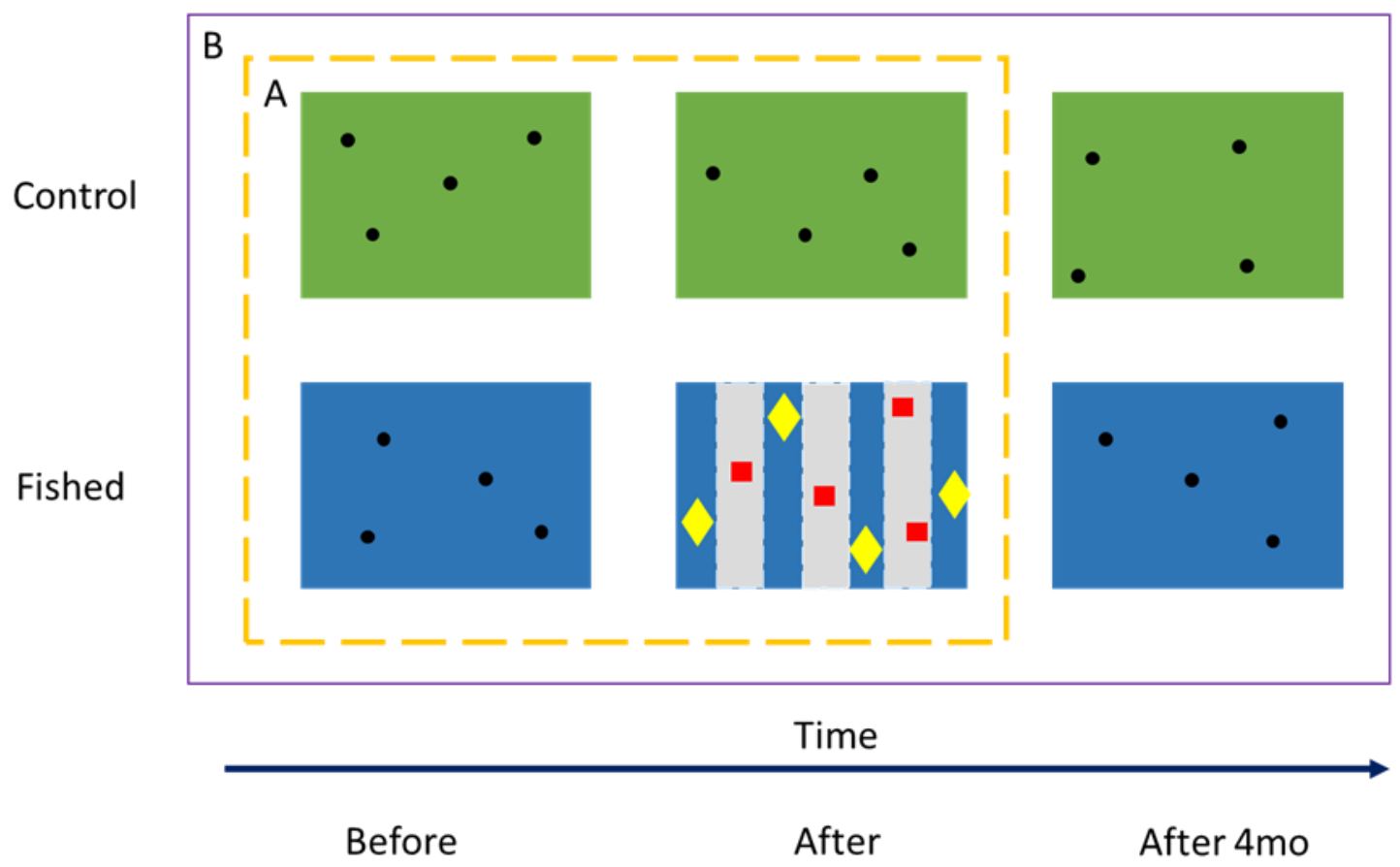

Figure 3. Experimental design comprising two sites and three time intervals. Dashed yellow line (A) direct/indirect effect of dredging: sampling undertaken before and after dredging. Black dots denote random samples from within the site. Two impact treatments are shown in the fished site (after): red dots within the gray bands denote samples taken within the dredge track; yellow dots within the blue area denote samples taken adjacent to the dredge track. Solid purple line (B) Short-term effects of dredging: sampling undertaken before, after, and after 4 mo.

\section{Data Collection and Processing}

Benthic macrofaunal samples were collected using SCUBA and a handheld sediment corer (HAPS; $\varnothing 136 \mathrm{~mm}, \mathrm{~L} ; 315 \mathrm{~mm}, \mathrm{~V} ; 4.5 \mathrm{~L}$ ) at a depth of $4.5 \mathrm{~m}$. The HAPS corer was chosen as it is the most commonly used sampler in Danish coastal waters and is used in annual benthic monitoring under the Danish national monitoring program (Hansen 2012). With as much accuracy as possible, samples were taken from a central position within similar-sized mussel patches. Four replicate core samples were taken from each treatment at each sampling time (Fig. 3). The cores were brought to the surface and sieved through a 1-mm sieve before preservation in $80 \%$ ethanol (EtOH). In the laboratory, organisms were removed from the sediment residue and identified to species level where possible. Identification was aided using taxonomic keys (Kirkegaard 1992a, Kirkegaard 1992b, Tebble 1976, Lincoln 1979) and online taxonomic resources (e.g., species-identification.org; naturalhistory.museumwales.ac.uk). Verification of nomenclature was based on WoRMs (marinespecies.org; 10/09/21). Individual taxa were counted and biomass (ash-free dry weight) was determined after incineration at $550^{\circ} \mathrm{C}$.

\section{Biological Traits}

Biological Trait Analysis uses the morphological, behavioral, and reproductive traits of taxa as indicators of ecological function (Bremner et al. 2006). The 10 trait categories chosen for analysis are shown in Table 1, which describe the functional composition of the associated macrofauna based on an existing trait database (Bolam et al. 2017). These trait categories were chosen based on their expected sensitivity to dredging disturbance. The 10 trait categories were subdivided into trait modalities (Table 1). As some taxa may exhibit more than one trait modality within a trait category, the traits were "fuzzy coded." Fuzzy coding uses a scale of 0-3 to rank taxa affinity to each trait 
modality (zero equals no affinity, and three equals full affinity) (Chevenet et al. 1994). The fuzzy coded trait categories were standardized to 1 , such that the trait modalities made up a proportion of the trait category. The trait scores were subsequently multiplied by the density of each taxa per site, which gave a density-weighted trait by site matrix used for analysis. Biological trait information was coded for the species identified in this study from the EU BENTHIS database (Bolam et al. 2017). Where taxa were not coded in the BENTHIS database, relevant literature was used to code taxa trait profiles. 
TABLE 1.

Biological traits and corresponding trait modalities analysed in the study.

\begin{tabular}{|c|c|c|c|c|c|c|c|}
\hline $\begin{array}{l}\text { Biological trait } \\
\text { category }\end{array}$ & Modalities & $\begin{array}{l}\text { Biological trait } \\
\text { category }\end{array}$ & Modalities & $\begin{array}{l}\text { Biological trait } \\
\text { category }\end{array}$ & Modalities & $\begin{array}{l}\text { Biological trait } \\
\text { category }\end{array}$ & Modalities \\
\hline \multirow[t]{6}{*}{ Size } & $10 \mathrm{~mm}$ & Feeding & Suspension & Living Habit & Tube dwelling & Bioturbation & Diffusive mixer \\
\hline & $11-20 \mathrm{~mm}$ & & Surface deposit. & & Burrow dwell & & Surface deposition \\
\hline & $21-100 \mathrm{~mm}$ & & Subsurf. deposit. & & Free living & & Up-conveyor \\
\hline & $101-200 \mathrm{~mm}$ & & Scavenger & & Crevice & & Down-conveyor \\
\hline & $201-500 \mathrm{~mm}$ & & Predator & & Endo/Epi-phytic & & \\
\hline & $>500 \mathrm{~mm}$ & & & & & & \\
\hline \multirow[t]{6}{*}{ Mobility } & Sessile & $\begin{array}{l}\text { Larval } \\
\text { Development }\end{array}$ & Planktotrophic & $\begin{array}{l}\text { Sediment } \\
\text { Position }\end{array}$ & Surface & Morphology & Exoskeleton \\
\hline & Crawl & & Lecithortrophic & & Infauna-top & & Soft \\
\hline & Swim & & Direct & & Infauna-mid & & Tunic \\
\hline & Burrow & & Budding & & Infauna-deep & & Crustose \\
\hline & & & & & & & Cushion \\
\hline & & & & & & & Stalked \\
\hline \multirow[t]{4}{*}{ Longevity } & $<1 \mathrm{yr}$ & Egg Development & Pelagic eggs & & & & \\
\hline & $1-2$ yrs & & Benthic eggs & & & & \\
\hline & $3-10$ yrs & & Brooding & & & & \\
\hline & $10+$ yrs & & & & & & \\
\hline
\end{tabular}




\section{Data Analysis}

\section{Univariate}

Statistical analyses were undertaken on three univariate community metrics, namely: density, species richness, and biomass. Generalized linear models were applied using a negative binomial, Poisson, and Gamma variance distribution for density, species richness, and biomass, respectively, in the "stats" package in R. Studio. The model was as follows:

$$
\mu_{i j}=\beta_{0}+\beta_{1} \operatorname{Tr}_{j}+\beta_{2} \mathrm{~T}_{i}+\beta_{3} \operatorname{Tr} T+\varepsilon_{i j}
$$

Where $\mu_{\mathrm{ij}}$ denotes the response metric (density, species richness, and biomass). $\beta_{0}$ is the intercept of the model, $T_{\mathrm{j}}$ is the treatment (dredge track, adjacent to the track, and control). $T$ is the time interval associated with $\mu_{\mathrm{ij}}$. $\beta$ 's are the parameters for the predictors, where $\beta_{3}$ describes the interaction between treatment and time, i.e., the BACI interaction term and the key parameter for this type of analysis. $\varepsilon_{\mathrm{ij}}$ is the residuals for the model. As the species richness and biomass of macrofauna associated with Mytilus edulis correlates with mussel patch size (Norling \& Kautsky 2007), mussel abundance was included in the model. During model selection, M. edulis abundance was not significantly contributing to any of the model, and hence was not selected in the most parsimonious model.

\section{Multivariate}

To compare the differences in macrofaunal community composition and biological trait composition, a permutation-based analysis of variance (PERMANOVA) was carried out in Primer 7 (PERMANOVA add on) (Anderson et al. 2008). If a significant interaction in the main test was observed, it was followed by post hoc pairwise tests of time within site. A Similarity Percentage routine set at $70 \%$ was used to identify taxa or traits that contributed most to the dissimilarity between interacting time and treatment pairs. Macrofaunal composition required fourth root transformation to reduce within group dispersion, indicated by a significant PERMDISP test on nontransformed data. A nonsignificant PERMDISP result after transformation reduced uncertainty upon finding a significant main test PERMANOVA result. No transformation was necessary for the trait data.

\section{Dredge Track}

To quantify the direct impact within the dredge track, a statistical model compared the control and fished site before and after disturbance. "Before" samples were taken $14 \mathrm{~d}$ before experimental dredging, and "after" samples were taken $1 \mathrm{~d}$ post experimental dredging. In this analysis, the fished site samples after dredging were collected from within the dredge track (Fig. 3A: red squares).

\section{Adjacent to the Dredge Track}

To quantify the indirect effects of dredging adjacent to the dredge track (within $5 \mathrm{~m}$ ), a statistical model compared the control and fished site before and after dredging. Here, the fished site samples after dredging were taken adjacent to the dredge track (Fig. 3A: yellow diamonds).

\section{Short-Term Recovery (4 mo)}

To quantify the short-term recovery from dredging, the fished and control sites were compared at three time intervals [before, after $(1 \mathrm{~d}), 4$ mo after]. After $4 \mathrm{mo}$, it was no longer possible to see the dredge track and samples were taken randomly from within the fished site, conceivably from either track or adjacent area. To account for this, the dredge track and adjacent to the track samples "after" were combined in the analysis $(n=8)$. To evaluate the effect of combining the two "after" treatments, a model excluding time "after" was used for comparison. It showed that combining 
treatments resulted in a conservative estimate of impact, but overall had the same outcome. Thus, the model including time "after" was used for the analysis (Fig. 3B).

\section{Results}

\section{Community Composition}

In total, 525 individuals and 54 species were identified in the HAPS core samples, after removing all individuals of M. edulis. The species represented four phyla: Annelida, Mollusca, Crustacea, and Echinodermata. The Annelida were numerically dominant, contributing $73 \%$ of total density, followed by Crustacea, (23\%), Mollusca (3\%), and Echinodermata (1\%). In terms of species richness, Annelida and Crustacea made up the majority of species with 26 and 19 species, respectively ( $48 \%$ and 35\%). Additionally, seven species of Mollusca and one species of Echinodermata were identified. The polychaete Capitella capitata (Blaineville, 1828) was found in high density and made up 43\% (227 individuals) of the total density. Taxa such as the amphipod Microdeutopus sp. were also abundant contributing to $7 \%$ of total density (37 individuals). As expected, samples from September, after summer recruitment, exhibited the greatest density and species richness.

\section{Dredge Track}

A decline in macrofaunal density and species richness within the dredge track (Fig. 4) resulted in a significant BACI interaction term $\left(\beta_{3}\right)$ (Table 2). Of the 10 most common taxa, five taxa decreased in density after dredging in the fished site [Microdeutopus gryllotalpa (Costa 1853), Mediomastus fragilis (Rasmussen 1973), Pseudopolydora pulchra (Carazzi 1893), Tubifex sp., Kurtiella bidentata (Gofas \& Salas 2008)], whereas three species increased [Capitella capitata, Harmothoe impar (Kinberg 1856), Harmothoe imbricata (Kinberg 1856)] and two remained the same (Table 3). The density and species richness increased in the control site after dredging, which strengthened the significant interaction. In contrast, no effect of dredging was observed on biomass in the dredge track. The PERMANOVA analysis of biological trait scores showed a significant interaction (pseudo F 4.73, $P=0.003$ ), indicating that dredging also had an effect on biological trait composition (Table 4). The biological traits that differed after dredging were remarkably similar at both sites (Table 5). The difference was that all the biological traits declined in the dredge track, and increased in the control site (Table 5). Of the 10 biological traits studied, nine declined in the dredge track. These included sediment position (infaunal-top), living habit (burrow dwelling), egg development (brooding), mobility (sessile), morphology (soft), longevity (1-2 y), larval development (planktonic, direct development), feeding mode (subsurface deposit), and size (21-100 mm). No significant effect of dredging was detected on multivariate community composition in the dredge track (Table 4). 

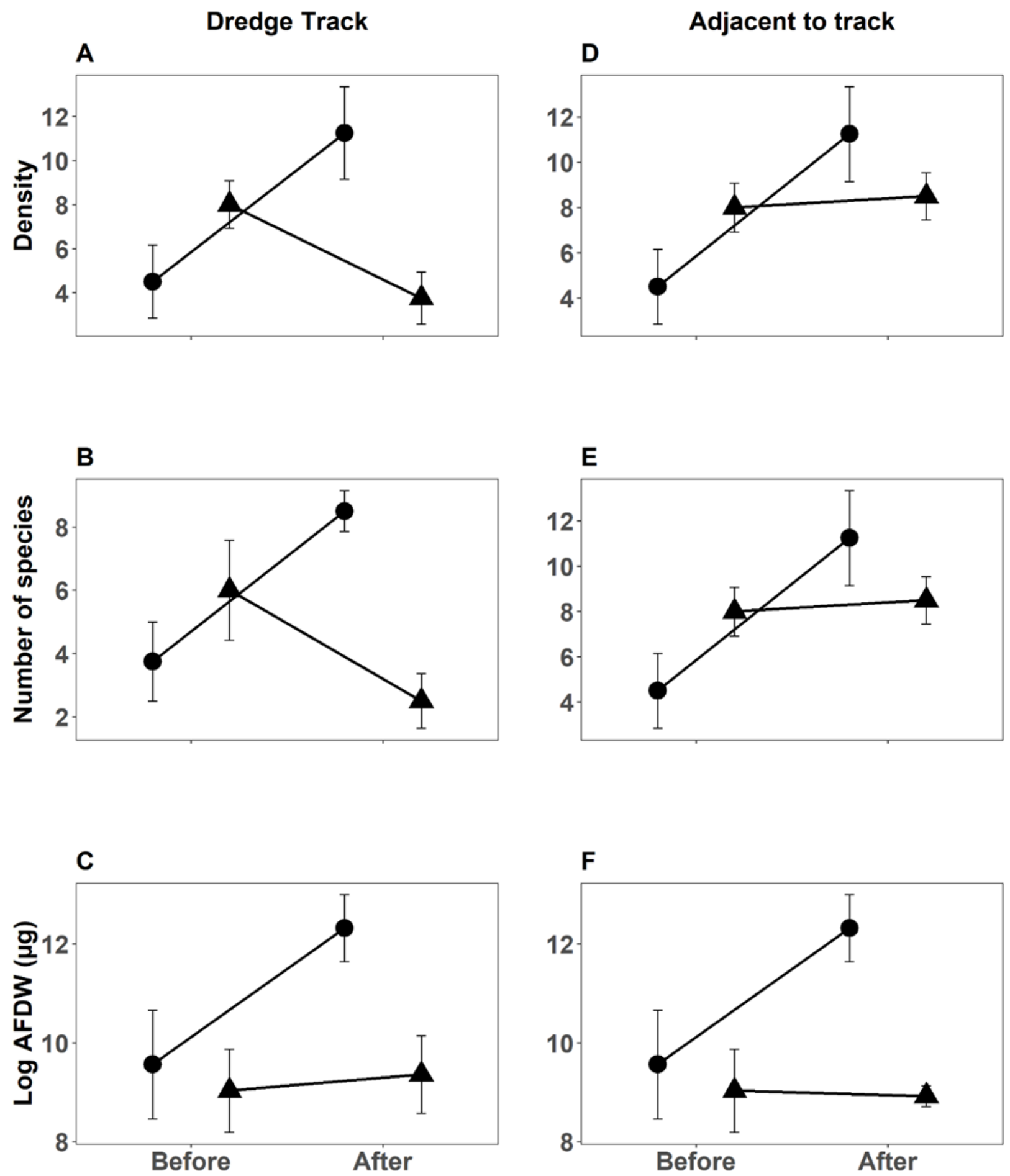

Figure 4. The mean $( \pm \mathrm{SE})(\mathrm{A}, \mathrm{D})$ macrofaunal density, $(\mathrm{B}, \mathrm{E})$ species richness, $(\mathrm{C}, \mathrm{F})$ biomass before dredging and after dredging in the control site (circles) and impact site (triangles). Asterisk indicates significant interaction level $(* * *<0.001, * *<0.01, *<0.05)$. 
TABLE 2.

Analysis of Variance (likelihood ratio test) of Generalised Linear Models for response variables (density, species richness, biomass) in the dredge track, adjacent to the track and four months after dredging.

\begin{tabular}{|c|c|c|c|}
\hline & LR Chisq & Df & $P$ value \\
\hline \multicolumn{4}{|c|}{ Dredge track: density } \\
\hline Treatment & 2.33 & 1 & 0.12 \\
\hline Time & 0.91 & 1 & 0.34 \\
\hline Treatment $x$ Time & 17.33 & 1 & $>0.0001^{\star \star \star}$ \\
\hline \multicolumn{4}{|c|}{ Dredge track: species richness } \\
\hline Treatment & 2.72 & 1 & 0.1 \\
\hline Time & 0.30 & 1 & 0.5 \\
\hline Treatment $x$ Time & 13.20 & 1 & $0.0002^{\star \star *}$ \\
\hline \multicolumn{4}{|c|}{ Dredge track: biomass } \\
\hline Treatment & 3.77 & 1 & $0.05^{\star}$ \\
\hline Time & 2.93 & 1 & 0.08 \\
\hline Treatment $\times$ Time & 1.16 & 1 & 0.28 \\
\hline \multicolumn{4}{|c|}{ Adjacent to the track: density } \\
\hline Treatment & 0.06 & 1 & 0.79 \\
\hline Time & 6.58 & 1 & $0.01^{\star *}$ \\
\hline Treatment $x$ Time & 5.44 & 1 & $0.02^{*}$ \\
\hline \multicolumn{4}{|c|}{ Adjacent to track species: richness } \\
\hline Treatment & 0.01 & 1 & 0.92 \\
\hline Time & 4.48 & 1 & $0.05^{\star}$ \\
\hline Treatment $\times$ Time & 3.15 & 1 & 0.09 \\
\hline \multicolumn{4}{|c|}{ Adjacent to the track: biomass } \\
\hline Treatment & 6.12 & 1 & $0.01^{\star \star}$ \\
\hline Time & 2.76 & 1 & 0.09 \\
\hline Treatment $x$ Time & 2.28 & 1 & 0.13 \\
\hline \multicolumn{4}{|c|}{ Short term: density } \\
\hline $\begin{array}{l}\text { Treatment } \\
\text { Time }\end{array}$ & $\begin{array}{l}0.6 \\
186.7\end{array}$ & $\begin{array}{l}1 \\
2\end{array}$ & $\begin{array}{l}0.44 \\
<0.0001^{\star * *}\end{array}$ \\
\hline Treatment $x$ Time & 8.4 & 2 & $0.01^{*}$ \\
\hline \multicolumn{4}{|c|}{ Short-term: species richness } \\
\hline Treatment & 7.5 & 1 & $0.006^{\star \star \star}$ \\
\hline Time & 10.4 & 2 & $0.005^{\star \star \star}$ \\
\hline Treatment $x$ Time & 9.6 & 2 & $0.008^{\star \star \star}$ \\
\hline \multicolumn{4}{|c|}{ Short-term: biomass } \\
\hline Treatment & 21.1 & 1 & $<0.0001^{\star \star \star}$ \\
\hline Time & 5.6 & 2 & 0.06 \\
\hline Treatment $\times$ Time & 0.7 & 2 & 0.7 \\
\hline
\end{tabular}


TABLE 3.

Average density (SD) of the most abundant taxa before and after dredging the three treatments (control, dredge track, and adjacent to the track).

\begin{tabular}{|c|c|c|c|c|c|c|c|c|}
\hline & \multicolumn{3}{|c|}{ Control } & \multicolumn{2}{|c|}{ Dredge track } & & \multicolumn{2}{|c|}{ Adjacent track } \\
\hline Species & Before & After & & Before & After & & Before & After \\
\hline Capitella capitata & $1(0.8)$ & $0.25(0.5)$ & $\downarrow$ & $0.25(0.5)$ & $0.75(0.96)$ & $\uparrow$ & $0.25(0.5)$ & 0 \\
\hline Microdeutopus & & & & & & & & \\
\hline $\begin{array}{l}\text { grylloptalpa } \\
\text { Semibalanus }\end{array}$ & 0 & $0.5(0.5)$ & 1 & $0.75(0.95)$ & 0 & $\downarrow$ & $0.75(0.95)$ & $0.5(0.5)$ \\
\hline balanoides & 0 & $1.75(3.5)$ & T & 0 & 0 & & 0 & $1(0.8)$ \\
\hline Mediomastus fragilis & $0.75(0.5)$ & $1.75(2.2)$ & $\uparrow$ & $2.25(1.8)$ & $0.75(0.96)$ & $\downarrow$ & $2.25(1.8)$ & $0.75(0.9)$ \\
\hline Harmothoe impar & $0.75(0.5)$ & $1.25(0.9)$ & $\uparrow$ & $0.5(0.5)$ & $1(0.5)$ & $\uparrow$ & $0.5(0.5)$ & $2(0.8)$ \\
\hline Harmothoe imbricata & 0 & 0 & & 0 & $0.25(0.5)$ & $\uparrow$ & 0 & 0 \\
\hline Caprella linearis & $0.25(0.5)$ & $0.5(0.5)$ & $\uparrow$ & 0 & 0 & & 0 & 0 \\
\hline $\begin{array}{l}\text { Pseudopolydora } \\
\text { pulchra }\end{array}$ & 0 & $0.75(0.95)$ & T & $0.25(0.5)$ & 0 & $\downarrow$ & $0.25(0.5)$ & $1.25(1.2)$ \\
\hline Psamathe fusca & $0.5(1)$ & $1.25(0.5)$ & $\uparrow$ & $0.25(0.5)$ & $0.25(0.5)$ & & $0.25(0.5)$ & 0 \\
\hline Tubifex sp. & $0.5(1)$ & $0.25(0.5)$ & $\downarrow$ & $0.25(0.5)$ & 0 & $\downarrow$ & $0.25(0.5)$ & $0.5(0.5)$ \\
\hline Kurtiella bidentata & $0.25(0.5)$ & 0 & $\downarrow$ & $0.75(0.5)$ & 0 & $\downarrow$ & $0.75(0.5)$ & 0 \\
\hline
\end{tabular}

Arrows indicate whether the change over time is positive $(\uparrow)$ or negative $(\downarrow)$.

\section{Adjacent to the Dredge Track}

A significant interaction on macrofaunal density was observed adjacent to the track (Table 2). Yet, unlike in the dredge track, density remained relatively stable in the area adjacent to the track, and the significant interaction term was driven by an increase in density in the control (Fig. 4). The higher density in the control site occurred as a result of the emergence of new taxa, and an increase in density of most taxa already present before dredging (Table 6). The main effect "Time" was the only significant predictor for species richness adjacent to the track (Table 2) suggesting changes over time had a greater effect on species richness than dredging in the adjacent area. Similar to in the dredge track, no effect of dredging on biomass was recorded (Table 2). Further, there was no indication of an effect of dredging on the biological traits examined or the community composition (Table 4). 
TABLE 4.

PERMANOVA results showing differences in trait composition and community composition before and after dredging.

Traits composition

Community composition

\begin{tabular}{|c|c|c|c|c|c|c|c|c|c|c|c|}
\hline & Source & $\mathrm{df}$ & SS & MS & Pseudo-F & $\begin{array}{c}\mathrm{P} \\
(\text { perm) }\end{array}$ & df & SS & MS & Pseudo-F & $\begin{array}{c}\mathrm{P} \\
\text { (perm) }\end{array}$ \\
\hline \multirow{3}{*}{$\begin{array}{l}\text { Dredge } \\
\text { track }\end{array}$} & Treatment & 1 & 626.3 & 626.3 & 0.628 & 0.7 & 1 & $1,375.7$ & $1,375.7$ & 0.5122 & 0.8 \\
\hline & Time & 1 & 798.19 & 798.19 & 0.8 & 0.5 & 1 & $1,800.9$ & $1,800.9$ & 0.6704 & 0.7 \\
\hline & $\begin{array}{l}\text { Time } \times \\
\text { Treatment }\end{array}$ & 1 & $4,713.6$ & $4,713.6$ & 4.726 & $0.003 * *$ & 1 & $5,094.8$ & $5,094.8$ & 1.8967 & 0.07 \\
\hline \multirow{3}{*}{$\begin{array}{l}\text { Adjacent } \\
\text { to track }\end{array}$} & Treatment & 1 & 988.3 & 988.3 & 1.215 & 0.2 & 1 & 3,789 & 3,789 & 1.628 & 0.1 \\
\hline & Time & 1 & $2,037.3$ & $2,037.3$ & 2.505 & $0.02 *$ & 1 & $3,642.1$ & $3,642.1$ & 1.5648 & 0.1 \\
\hline & $\begin{array}{l}\text { Time } \times \\
\text { Treatment }\end{array}$ & 1 & $1,221.5$ & $1,221.5$ & 1.502 & 0.15 & 1 & $2,558.7$ & $2,558.7$ & 1.0998 & 0.4 \\
\hline \multirow{3}{*}{$\begin{array}{l}\text { Short } \\
\text { term }\end{array}$} & Treatment & 1 & 583.9 & 583.9 & 0.687 & 0.5 & 1 & $2,383.7$ & $2,383.7$ & 1.0163 & 0.4 \\
\hline & Time & 2 & 23,584 & 11,792 & 13.87 & $0.001 * *$ & 2 & 17,159 & $8,579.4$ & 3.6579 & $0.001 * *$ \\
\hline & $\begin{array}{l}\text { Time } \times \\
\text { Treatment }\end{array}$ & 2 & $3,327.2$ & $1,663.6$ & 1.956 & 0.07 & 2 & $5,978.7$ & $2,989.4$ & 1.2745 & 0.2 \\
\hline
\end{tabular}

The response was analyzed in the dredge track (direct effect), adjacent to the track (indirect effects), and after 4 mo (short-term effects). Asterisk indicates the significance level: $* * *<0.001$, $* *<0.01, *<0.05$. PERMANOVA, permutation-based analysis of variance. 
TABLE 5.

SIMPER analysis showing the differences in trait composition in the control and the fished site before and after dredging.

Control site

\begin{tabular}{|c|c|c|c|c|c|c|}
\hline Trait modality & $\begin{array}{l}\text { Before Av. } \\
\text { abundance }\end{array}$ & $\begin{array}{l}\text { After Av. } \\
\text { abundance }\end{array}$ & Av.Diss & Diss/SD & Contrib \% & Cum.\% \\
\hline Soft & 3.75 & $7.5 \uparrow$ & 3.07 & 1.38 & 6.07 & 6.07 \\
\hline Surf-depos & 1.88 & $6.38 \uparrow$ & 2.93 & 1.98 & 5.8 & 11.86 \\
\hline brood & 3.4 & $7.19 \uparrow$ & 2.57 & 1.3 & 5.08 & 16.95 \\
\hline Crawl & 1.67 & $4.92 \uparrow$ & 2.38 & 1.73 & 4.69 & 21.64 \\
\hline yr1-2 & 3.13 & $5.5 \uparrow$ & 2.14 & 1.39 & 4.22 & 25.86 \\
\hline Plankto & 2.33 & $5.83 \uparrow$ & 2.08 & 0.98 & 4.11 & 29.97 \\
\hline Surface & 1.56 & $4.13 \uparrow$ & 2.04 & 1.65 & 4.03 & 34 \\
\hline $21-100 \mathrm{~mm}$ & 2.58 & $5.17 \uparrow$ & 1.98 & 1.52 & 3.91 & 37.92 \\
\hline Burrow-dwelling & 1.19 & $4.06 \uparrow$ & 1.82 & 1.4 & 3.59 & 41.5 \\
\hline Sessile & 2.63 & $4.25 \uparrow$ & 1.79 & 1.1 & 3.54 & 45.04 \\
\hline Inf-top & 2.31 & $4.96 \uparrow$ & 1.77 & 0.94 & 3.5 & 48.54 \\
\hline Direct & 1.27 & $3.08 \uparrow$ & 1.7 & 1.45 & 3.36 & 51.9 \\
\hline Exoskeleton & 0.75 & $3.5 \uparrow$ & 1.69 & 1.07 & 3.34 & 55.24 \\
\hline Free-living & 1.37 & $3.29 \uparrow$ & 1.66 & 1.5 & 3.27 & 58.52 \\
\hline eggs-pel & 0.58 & $2.5 \uparrow$ & 1.54 & 1.54 & 3.03 & 61.55 \\
\hline yr3-10 & 0.88 & $3 \uparrow$ & 1.51 & 1.36 & 2.98 & 64.53 \\
\hline Pred & 1.33 & $3.05 \uparrow$ & 1.44 & 1.42 & 2.84 & 67.37 \\
\hline Surf-Dep & 0.16 & $2.4 \uparrow$ & 1.39 & 2.32 & 2.15 & 70.12 \\
\hline
\end{tabular}

Fished site (dredge track)

\begin{tabular}{|c|c|c|c|c|c|c|}
\hline Inf-top & 5.85 & $2 \downarrow$ & 3.45 & 2.58 & 6.89 & 6.89 \\
\hline Burrow-dwelling & 3.94 & $0.38 \downarrow$ & 3.03 & 3.23 & 5.78 & 18.73 \\
\hline brood & 5.65 & $2.63 \downarrow$ & 2.89 & 1.58 & 5.36 & 24.09 \\
\hline Sessile & 4.63 & $1.5 \downarrow$ & 2.68 & 1.59 & 5.33 & 29.42 \\
\hline Soft & 6.25 & $3.5 \downarrow$ & 2.67 & 1.45 & 5.15 & 34.57 \\
\hline yr1-2 & 5.25 & $2.38 \downarrow$ & 2.58 & 2.3 & 4.86 & 39.43 \\
\hline Plankto & 4.46 & $2.75 \downarrow$ & 2.43 & 1.2 & 4.05 & 43.48 \\
\hline Subsurf-dep & 3.5 & $1.5 \downarrow$ & 2.03 & 1.24 & 3.75 & 47.23 \\
\hline $21-100 \mathrm{~mm}$ & 4.28 & $2.5 \downarrow$ & 1.88 & 1.52 & 3.67 & 50.9 \\
\hline Direct & 2.33 & $0.5 \downarrow$ & 1.84 & 1.71 & 3.65 & 54.55 \\
\hline Surf-depos & 3.19 & $1.75 \downarrow$ & 1.83 & 1.3 & 3.55 & 58.11 \\
\hline Surf-Dep & 2.16 & $0.19 \downarrow$ & 1.78 & 1.59 & 3.23 & 61.34 \\
\hline yr3-10 & 2.25 & $1.13 \downarrow$ & 1.62 & 1.29 & 3.21 & 64.54 \\
\hline Up-Conveyor & 2.56 & $0.94 \downarrow$ & 1.61 & 1.05 & 2.77 & 67.31 \\
\hline Exoskeleton & 1.75 & $0.25 \downarrow$ & 1.39 & 1.95 & 2.77 & 70.08 \\
\hline $10 \mathrm{~mm}$ & 1.58 & $0 \downarrow$ & 1.39 & 1.98 & 6.05 & 12.95 \\
\hline
\end{tabular}


Arrows indicate whether the change over time is positive $(\uparrow)$ or negative $(\downarrow)$. SIMPER, Similarity Percentage.

\section{Short-Term Effect}

Four months after dredging species richness remained low, possibly suggesting a longer-term impact compared with that of density or biomass (Fig. 5). Species richness declined immediately after dredging in the fished site, and then showed signs of recovery after 4 mo (Fig. 5). After 4 mo, three of the ten most common species were absent from the fished site (Microdeutopus grylloptalpa, Tubifex sp., Kurtiella bidentata) (Table 7). In addition, the diversity of amphipods was particularly low in the fished site. Here, only four species of amphipod were recorded after 4 mo, of which there were five individuals. In contrast, the control site had eight species with 59 individuals. Although the density of macrofauna declined immediately after dredging, a considerable increase occurred thereafter, resulting in a similar macrofaunal density in the fished site as in the control site after 4 mo (Fig. 5). This indicates that the effect of dredging on macrofaunal density did not persist for the 4-mo study period. In both sites, the density increased after 4 mo mainly due to a single species of opportunistic polychaete, Capitella capitata, which made up $60 \%$ and $81 \%$ of the density in the control and fished site, respectively. Biomass was observed to remain relatively stable over the study period (Fig. 5), and accordingly no short-term effect of dredging was detected on macrofaunal biomass (Table 2). The results of the PERMANOVA analysis indicated that there were no significant interactions on biological trait composition, which suggests that dredging did not impact the biological trait composition of the community in the short term (Table 4). Finally, there was no effect of dredging on macrofaunal community composition as indicated by the nonsignificant PERMANOVA interaction term (Table 4). 

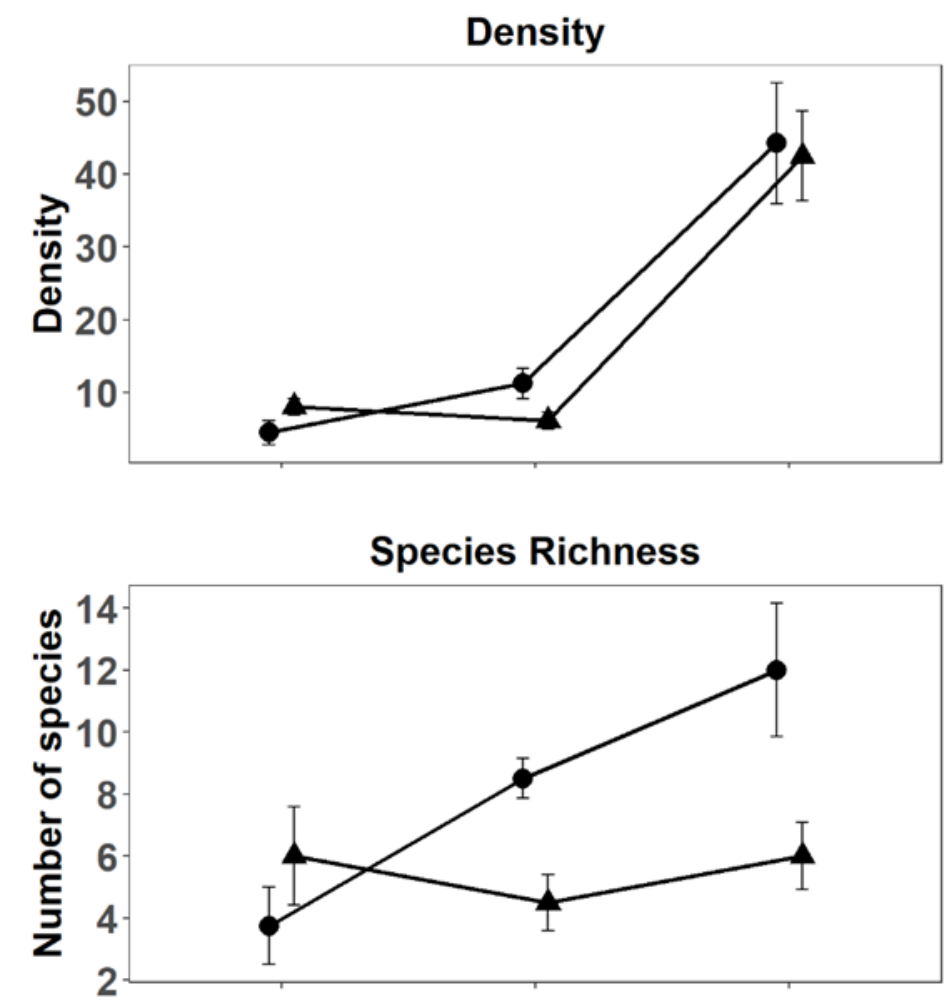

\section{Biomass}

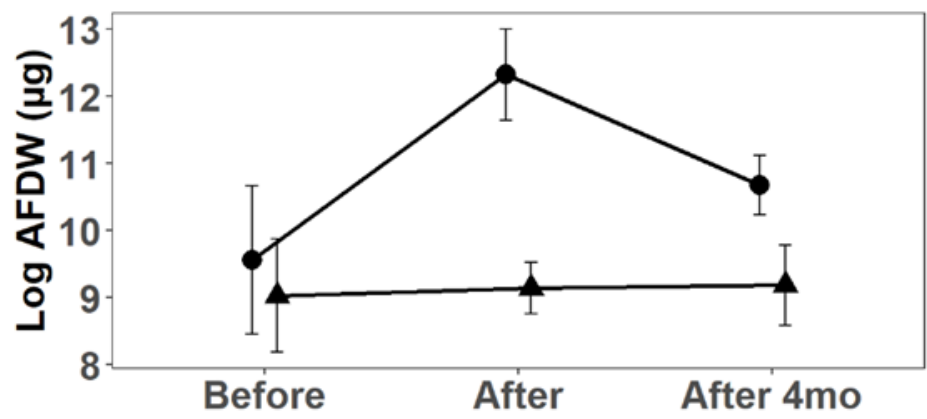

Figure 5. The difference in macrofaunal density, species richness, biomass $( \pm \mathrm{SE})$ before dredging, after dredging, and 4 mo after dredging in the control site (circles) and fished site (triangles). Asterisk indicates significant interaction level $(* * *<0.001, * *<0.01, *<0.05)$. 
TABLE 6.

Species differences in the control site before and after fishing.

\begin{tabular}{|c|c|c|c|}
\hline Before (9) & After (21) & Change & \\
\hline & Asterias & +1 & $\uparrow$ \\
\hline \multirow[t]{2}{*}{ Alitta succinea (1) } & Alitta succinea (2) & +1 & $\uparrow$ \\
\hline & Alitta virens & +2 & $\uparrow$ \\
\hline Capitella capitata (4) & Capitella capitata (1) & -3 & $\downarrow$ \\
\hline \multirow[t]{5}{*}{ Caprella linearis (1) } & Caprella linearis (2) & +1 & $\uparrow$ \\
\hline & Corophium & +1 & $\uparrow$ \\
\hline & Ensis ensis & +1 & $\uparrow$ \\
\hline & Eunereis & +1 & $\uparrow$ \\
\hline & Gammarus & +2 & $\uparrow$ \\
\hline \multirow[t]{3}{*}{ Harmothoe impar (3) } & Harmothoe impar (5) & +2 & $\uparrow$ \\
\hline & Heteromastus & +1 & $\uparrow$ \\
\hline & Hinia & +1 & $\uparrow$ \\
\hline Kurtiella bidentata (1) & Kurtiella bidentata (2) & +1 & $\uparrow$ \\
\hline \multirow[t]{2}{*}{ Mediomastus fragilis (3) } & Mediomastus fragilis (7) & +4 & $\uparrow$ \\
\hline & Microdeutopus gryllotalpa & +2 & $\uparrow$ \\
\hline Mya arenaria $(1)$ & Mya arenaria (2) & +1 & $\uparrow$ \\
\hline \multirow[t]{4}{*}{ Psamathe fusca (2) } & Psamathe fusca (5) & +3 & $\uparrow$ \\
\hline & Pseudopolydora & +3 & $\uparrow$ \\
\hline & Scoloplos armiger & +2 & $\uparrow$ \\
\hline & Semibalanus balanoides & +7 & $\uparrow$ \\
\hline Tubificidae (2) & Tubificidae (1) & -1 & 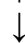 \\
\hline
\end{tabular}

Number of individuals shown in brackets. Arrows indicate whether the change over time is positive ( $\uparrow)$ or negative ( $\downarrow)$.

TABLE 7.

The average density of the 10 most abundant taxa "before," "after," and "4 mo after" dredging in the control and fished site.

\begin{tabular}{|c|c|c|c|c|c|c|c|c|c|c|}
\hline & Control & & & & & Fished & & & & \\
\hline & Before & After & & 4 mo after & & Before & After & & 4 mo after & \\
\hline Capitella capitata & 1 & 0.25 & $\downarrow$ & 19.25 & $\uparrow$ & 0.25 & 0.375 & $\uparrow$ & 35.25 & $\uparrow$ \\
\hline Microdeutopus grylloptalpa & 0 & 0.5 & $\uparrow$ & 7.25 & $\uparrow$ & 0.75 & 0.25 & $\downarrow$ & 0 & $\downarrow$ \\
\hline Semibalanus balanoides & 0 & 1.75 & $\uparrow$ & 3.25 & $\uparrow$ & 0 & 0.5 & $\uparrow$ & 0.5 & $\uparrow$ \\
\hline Mediomastus fragilis & 0.75 & 1.75 & $\uparrow$ & 2.5 & $\uparrow$ & 2.25 & 0.75 & $\downarrow$ & 0.25 & $\downarrow$ \\
\hline Harmothoe impar & 0.75 & 1.25 & $\uparrow$ & 0.5 & $\downarrow$ & 0.5 & 1.125 & $\uparrow$ & 0.5 & \\
\hline Harmothoe imbricata & 0 & 0 & & 2 & $\uparrow$ & 0 & 0.125 & $\uparrow$ & 2 & $\uparrow$ \\
\hline Caprella linearis & 0.25 & 0.5 & $\uparrow$ & 2.25 & $\uparrow$ & 0 & 0 & & 0.5 & $\uparrow$ \\
\hline Pseudopolydora pulchra & 0 & 0.75 & $\uparrow$ & 0 & $\downarrow$ & 0.25 & 0.625 & $\uparrow$ & 0.75 & $\uparrow$ \\
\hline Psamathe fusca & 0.5 & 1.25 & $\uparrow$ & 0 & $\downarrow$ & 0.25 & 0.125 & $\uparrow$ & 0.25 & \\
\hline Tubifex sp. & 0.5 & 0.25 & $\downarrow$ & 0.75 & $\uparrow$ & 0.25 & 0.25 & & 0 & $\downarrow$ \\
\hline Kurtiella bidentata & 0.25 & 0 & $\downarrow$ & 0 & $\downarrow$ & 0.75 & 0 & $\downarrow$ & 0 & $\downarrow$ \\
\hline
\end{tabular}

Arrows indicate whether the change over time is positive $(\uparrow)$ or negative $(\downarrow)$. 


\section{Discussion}

\section{Direct Effects of the Light Dredge}

The physical impacts to the seabed from fishing gears, besides removing the target species and habitat materials, arise from two processes (O’Neill \& Ivanović 2016). First, there are pressuredriven changes that occur as the gear physically interacts with the seabed and leads to gear penetration, shearing, and lateral distribution of sediments (O'Neill \& Ivanović 2016). Second, hydrodynamic processes at the wake of the gear generates turbulence and pressure drop, leading to the mobilization of sediment (O'Neill \& Ivanović 2016). The immediate decline in density and species richness shown in the dredge track is thought to be caused by the former, i.e., the direct physical interaction with the gear. The dredge itself consists of a metal frame and a polyethylene collection bag, which create a relatively homogenous impact across the footprint (Eigaard et al. 2016). Within the width of the gear and length of the path (i.e., gear footprint), the benthos are first impacted by the iron frame, followed by the trailing 177-cm long netted bag (Fig. 2). Direct contact with the iron frame likely causes the greatest impact, potentially crushing infauna with exoskeletons such as thin-shelled bivalves (Rumohr \& Krost 1991) and crustaceans. The netted bag may be less impactful, but has the potential to snag and tear soft-bodied benthos such as polychaetes and ascidians. Accordingly, a relatively greater mortality can be expected from the direct physical interaction with the gear (Bergman \& Van Santbrink 2000), compared with indirect effects from the mobilization of sediments. For that reason many experimental fishing studies have reported a decline in the density (Hall et al. 1990, Thrush et al. 1995, Carvalho et al. 2011), species richness (Hall et al. 1990, Thrush et al. 1995, Dolmer et al. 2001, Carvalho et al. 2011), and biomass (Carvalho et al. 2011) of macrofauna in the days after fishing impact.

The light dredge is designed to reduce the physical impact to the seabed, and compared with the traditional Dutch dredge, the sediment retention and drag is significantly reduced (Frandsen et al. 2015). A lack of gear trials meant making a direct comparison of the macrofaunal depletion from the Dutch dredge and light dredge not possible. Even so, a similar study was undertaken in the Løgstør Broad using a scaled model of the Dutch dredge, roughly a third of the size and weight of the commercial configuration (Dolmer et al. 2001). In the study, species richness was significantly affected by dredging, and reported to decline by approximately $33 \% 40 \mathrm{~d}$ after dredging. In comparison, this study showed that the light dredge resulted in a $44 \%$ decrease in species richness 1 $\mathrm{d}$ after dredging. The greater depletion of species in this study may be caused by the heavier gear weight. The down-scaled model used by Dolmer et al. (2001) weighed approximately $80 \mathrm{~kg}$, compared with the commercial light dredge that weighed $123 \mathrm{~kg}$. The weight and towing speed of fishing gears determines the penetration into the sediment (Rijnsdorp et al. 2016), and gear penetration depth correlates with benthic macrofaunal mortality (Sciberras et al. 2018). Therefore, as the Dutch dredge weighs $235.6 \mathrm{~kg}$ (approximately double the weight of the light dredge), it can be assumed that the switch to the light dredge will have resulted in reduced macrofaunal depletion from fishing.

The depletion of benthic fauna can be influenced by the morphological, behavioral, and reproductive characteristics. Certain biological traits are known to be more sensitive to trawling than others (Thrush \& Dayton 2002, de Juan et al. 2007) such as shell thickness (Rumohr \& Krost 1991), mobility (Thrush \& Dayton 2002), and egg development. Accordingly, a negative effect of dredging was found on the biological trait composition in the dredge track. Sensitive biological traits, such as shallow sediment position (infauna top: $0-5 \mathrm{~cm}$ ), low mobility (sessile), and soft morphology declined in the dredge track, however, so did the biological traits that are thought to be more tolerant to physical disturbance such as short life span (1-2 y), small size (10 mm, 21-100 mm), and hard morphology (exoskeleton). The general decline of biological traits in the dredge track suggests that dredging was not only detrimental to the sensitive traits, and instead may reflect the overall loss in density in the dredge track. 
In a BACI experimental design, a significant interaction usually implies a negative effect of the treatment, particularly if the significant interaction is caused by a decline in the impact site. Here, the significant interaction on density adjacent to the dredge track was driven by a higher density of macrofauna in the control site. As these results are not derived from a decline in the fished site, caution must be taken in the interpretation of the results.

A positive effect of time was shown for the density of macrofauna in the control site, which was not apparent in the fished site. The first and simplest explanation is patchy distribution.

Environmental parameters can vary over small spatial scales and as a consequence, macrofauna are patchily distributed. Adding to this, beds of Mytilus edulis are also known to be hot spots for biodiversity. Benthic macrofaunal density, biomass, species richness, and trait richness all increase with M. edulis density and patch size (Norling \& Kautsky 2007, McLaverty et al. 2020). Therefore, differences in $M$. edulis density, size structure, or biomass could drive differences in macrofaunal density and species richness. To mitigate the effect of mussel patch size, a diver made his best efforts to sample from a central position in similar-sized mussel patches. These efforts were reflected in the fact that the shell length and biomass of $M$. edulis were not significantly different after dredging in the control and adjacent area ( $t$-test comparing $M$. edulis shell length and biomass after dredging: $t=$ $1.6, \mathrm{Df}=4.1, P=0.2, t=0.6, \mathrm{Df}=3.5, P=0.6$, respectively). Although mussel density was significantly higher in the adjacent area after dredging than in the control $(t=93.1$, Df $=6, P=0.02)$, mussel density in the adjacent area did not differ before and after fishing $(t=0.2, \mathrm{df}=4.6, P=0.8)$. The lower macrofaunal density in the adjacent area associated with higher mussel density, relative to the control, is contrary to the positive effect of mussel density on macrofaunal density previously shown (Norling \& Kautsky 2007, McLaverty et al. 2020). Therefore, the results may reflect that the handheld sediment corer was not optimal for sampling larger epifauna like as M. edulis, and that differences in the mussel bed structure may still have existed between sites. In addition, an assumption was made that the sediment grain size were the same due to the close proximity of the sites to one another yet, a significant differences in the grain size of the top layer of sediment (0-2 $\mathrm{cm}$ ) was detected before experimental dredging took place, but no difference in the organic material (loss on ignition). These small-scale differences between sites could also have influenced the results.

One effect of dredging that perceivably affects the benthos indirectly is the mobilization of sediment. Sedimentation can smother benthic fauna if it exceeds natural levels and thus faunal tolerance (Miller et al. 2002). Sedimentation can also cause deterioration of water quality due to increased turbidity. An empirical-based model showed that the sediment plume from the light dredge in the Limfjord can extend 260-540 m depending on current speed, and that sediment resuspension was similar to background (natural) resuspension (Pastor et al. 2020). The model showed that fishing intensity correlated with sediment accumulation. Therefore, the comparatively higher fishing intensity in this study (approximately 28 dredge tracks $100 \cdot \mathrm{m}^{-2}$ vs. 4.5 dredge tracks $100 \cdot \mathrm{m}^{-2}$ ) may have led to higher sediment accumulation. Further, sediment accumulation was highest closest to the dredging activity (Pastor et al. 2020), which suggests that localized sediment accumulation could have been high in the dredge track and adjacent areas. Based on the sediment type (sand $>125 \mu \mathrm{m}$ ) it was estimated that $80 \%$ of the resuspended sediment would fall within $0.3-0.9 \mathrm{~m}$ from the dredge track. As sediment accumulation was not quantified in this study, it was not possible to conclude on whether sedimentation from dredging activity exceeded natural sedimentation. Further investigation into the extent of sediment accumulation in the adjacent areas would clarify whether sedimentation from dredging negatively affects benthic macrofauna.

\section{Short-Term Effects of the Light Dredge}

Seasonal recruitment causes macrofaunal density and species richness to increase from its lowest point at the onset of spring, to its highest in late autumn (Peterson \& Jensen 1911). In the Limfjord, 
recruitment follows a similar seasonal pattern. This has been disrupted in some years, where species richness remains at a constant low between spring and autumn, due to mass mortality caused by oxygen depletion (Hylleberg 1993). In this study, species richness remained relatively constant in the fished site from spring to autumn, whereas species richness increased in the control site. There was no indication of oxygen depletion at the study site during the study period. Therefore, the lack of increase in species richness may indicate a negative effect of dredging on recruitment. Nonetheless, whereas species richness was lower in the fished site than in the control, the trend 4 mo after dredging was positive, which may signify recovery was in progress. The recovery in terms of density was dominated by the polychaete Capitella capitata, which made up $81 \%$ and $60 \%$ of the density in the fished and control sites, respectively. This resulted in both sites having relatively low species richness, but high density, which is characteristic of benthic communities affected by eutrophication (Pearson \& Rosenberg 1987).

As organic enrichment increases, water quality deteriorates, and the number of species that can tolerate the conditions decline. Meanwhile, the proliferations of opportunistic taxa can occur (Pearson \& Rosenberg 1987). The polychaete Capitella capitata thrives in eutrophic conditions as it can tolerate hypoxic sediments (Macleod et al. 2008), expresses opportunistic reproduction (Qian \& Chia 1994), and rapidly colonizes defaunated patches (Bolam \& Fernandes 2002). The effect of eutrophication on the density of macrofauna may help explain the lack of detectable fishery effect in this part of the study, and may signify that density is a poor indicator of the short-term effects of dredging in eutrophic systems. It is recognized that the results of this study are limited to the discussion of impacts to the benthos over the short term, i.e., after 4 mo. Ideally, given the large structuring effect winter mortality can have on benthic communities, additional sampling would have taken place after the winter to fully assess recovery. This is of particular importance in systems such as the Limfjord where large fluctuations in temperature occurs between seasons. Given the practical and financial restraints of using diver-collected samples, this was not possible.

High levels of benthic disturbance, whether anthropogenic or natural, will shape macrofaunal community composition and select for biological traits that are more resilient to disturbance. Here, the results showed that while dredging negatively affected biological traits in the dredge track, no negative effect on biological traits was evident after 4 mo. This suggests that other environmental drivers may have a greater structuring effect on benthic composition than dredging in the Limfjord. These findings are also corroborated by the results of a large-scale gradient analysis of dredging effects in Danish Natura 2000 sites, where dredging intensity did not result in any significant impacts to trait composition or trait richness (McLaverty et al. 2020). This can occur as stressors such as nutrient pollution and hydrodynamic disturbance have a similar structuring effect on benthic trait composition as trawling, i.e., a dominance of small-bodied, short-lived, deposit feeding taxa (Macleod et al. 2008, Van Denderen et al. 2015). Given the century-long effect of nutrient enrichment in the area, it is not surprising that dredging is not the main driver of species and trait composition across the study area.

\section{Management Perspectives}

For the first time, these results provide an estimate for the depletion of benthic macrofauna, and information on the dynamics of recovery, directly relevant to the dredging gear used across the Danish mussel fishery. The Danish Mussel Policy was set up with the aim to regulate and sustainably manage fisheries in Natura 2000 sites, and permits vessels to impact $\leq 15 \%$ of the seabed cumulatively over a period of 2-5 y depending on recovery time of benthic fauna within a given Natura 2000 site (Foreign Ministry of Denmark 2019). As benthic macrofaunal depletion rates are not currently considered in the assessment of dredging impacts, the results are of particular relevance, and improve the understanding of dredging effects on seabed biota in the Løgstør Broad. Provided depletion rates are supplemented with depletion rates for the other main habitat types in the 
Limfjord, these can be combined with black box data to predict impacts quantitatively in areas that are not currently assessed (Rijnsdorp et al. 2016).

Of the biological metrics examined in this study, the results suggest that species richness was relatively sensitive to dredging, remaining in an altered state for up to $4 \mathrm{mo}$ after disturbance. This supports the observations of Dolmer et al. (2001), who observed that although species richness initially increased straight after dredging (due to an influx of scavengers), it subsequently declined and remained reduced for up to $40 \mathrm{~d}$ after. Species richness has been shown to be a more sensitive indicator of trawling than density in deeper $(35 \mathrm{~m}$ ) muddy benthic habitats (Ragnarsson \& Lindegarth 2009), and has been shown to remain impacted for up to 8 mo after experimental shrimp trawling (Tulp et al. 2020). To more accurately define the effect of dredging on species richness in the Limfjord, future studies may seek to undertake experiments over longer time periods than 4 mo. The choice to limit this experiment to 4 mo was mainly logistical, but also reflected normal dredging activity followed by a closed period during the summer months (from beginning of July to beginning of September).

The experiment was designed to target benthic communities that are representative of those impacted by this fishery. As a result, the macrofaunal depletion and recovery are described for communities associated with established mussel beds. Therefore, the results of this study may be less relevant for predicting depletion rates in other habitat types such as soft bottoms (sand and mud), which are not associated with biogenic structures. Until recently, the management of mussel fisheries in Denmark has used data collected from the Danish national monitoring program to estimates benthic community regeneration times in each Natura 2000 site. Notably, these monitoring data are collected in areas of Løgstør that do not support large or consolidated mussel beds. These reference communities may not be representative of those found in close association with mussel beds, and therefore impacted by the fishery. Compared with bare sand habitats, mussel beds in Løgstør are associated with higher benthic density and species richness (Ysebaert et al. 2009; McLaverty et al. 2020), and more generally, mussels significantly enhance benthic diversity in disturbed or eutrophic systems (Norling \& Kautsky 2008). It would be advantageous that the estimation of regeneration times are based on data collected from surveys such as this one, which target benthic communities found in association with dense mussel beds.

A cumulative impact of $15 \%$ of the seabed in Natura 2000 sites was considered suitable as it is lower than 25\%, which the European commission defines to be "unfavorable" for conservation status (Foreign Ministry of Denmark 2019). Nonetheless, the Biodiversity Strategy for 2030 proposes to have $30 \%$ of land and sea legally protected by 2030 of which $10 \%$ should be strictly protected, i.e., permanently closed to bottom-contacting fishing (European Commission 2020). Whereas the Natura 2000 site in the Løgstør Broad already meets this proposition, as a section of the Natura 2000 site is voluntarily closed to protect eelgrass beds, other Natura 2000 sites in Danish waters do not. The value of having areas permanently closed to bottom-contacting fishing, may not only to support biodiversity, but also enhance the ability to sustainably manage fisheries. A study carried out in the Limfjord and inner Danish waters showed that nonfished reference sites were essential for detecting dredging impacts (McLaverty et al. 2020). Therefore, permanently closed marine protected areas within the Natura 2000 network in European waters may be a consideration for future ecosystembased fisheries management.

\section{ACKNOWLEDGMENTS}

Thanks to Rune Frederiksen for his work diving for our data collection. Thanks to the crew from Foreningen Muslingeerhvervet that carried out the mussel dredging for our experiment and to the technicians from the Danish Shellfish Centre: Finn Bak, Niels-Peter Nielsen, Lars Kyed Andersen, Kasper Lenda Andersen, and Pascal Barreau. Finally, we thank the editor for the helpful comments and suggestions. This study was funded by the Danish Fisheries Agency, Ministry of Environment and Food of Denmark, through the European Maritime and Fisheries Fund (EMFF) via the projects: "Udvlkling af nye værktøjer til vurdering af miljøeffekter af fiskeri” (grant agreement number 33113-1-16- 
011), “Sandbanker og fiskeripåvirkning i relation til EU’s fiskeri- og miljøpolitik” (grant agreement No 33113-B-17108), "Påvirkning af økosystemkomponenten bundfauna i N2000 områder ved fiskeri med skrabende redskaber" (grant agreement number 33-113B-16-056), and "Udvikling af indikatorer til miljøvurdering af fiskerieffekter på marin bundfauna og habitater" (grant agreement number 33113-B-17-107), and DTU Aqua.

\section{Literature Cited}

Anderson, M., R. Gorley, K. Clarke. 2008. PERMANOVA+ for PRIMER: guide to software and statistical methods. https://doi.org/10.1002/9781118445112.stat07841

Bergman, M. J. N. \& J. W. Van Santbrink. 2000. Mortality in megafaunal benthic populations caused by trawl fisheries on the Dutch continental shelf in the North Sea in 1994. ICES J. Mar. Sci. 57:1321-1331. https://doi.org/10.1006/jmsc.2000.0917

Bolam, S. G., C. Garcia, J. Eggleton, A. J. Kenny, L. Buhl-Mortensen, G. Gonzalez-Mirelis, T. van Kooten, G. Dinesen, J. Hansen, J. G. Hiddink, M. Sciberras, C. Smith, N. Papadopoulou, A. Gumus, G. Van Hoey, O. R. Eigaard, F. Bastardie \& A. D. Rijnsdorp. 2017. Differences in biological traits composition of benthic assemblages between unimpacted habitats. Mar. Environ. Res. 126:1-13. https://doi.org/10.1016/j.marenvres.2017.01.004

Bolam, S. G. \& T. F. Fernandes. 2002. Dense aggregations of tube-building polychaetes: response to small-scale disturbances. J. Exp. Mar. Biol. Ecol. 269:197-222. https://doi.org/10.1016/S00220981(02)00003-5

Bremner, J., S. I. Rogers \& C. L. J. Frid. 2006. Matching biological traits to environmental conditions in marine benthic ecosystems. J. Mar. Syst. 60:302-316. https://doi.org/10.1016/j.jmarsys.2006.02.004

Carvalho, S., R. Constantino, F. Pereira, R. Ben-Hamadou \& M. B. Gaspar. 2011. Relationship between razor clam fishing intensity and potential changes in associated benthic communities. J. Shellfish Res. 30:309-323. https://doi.org/10.2983/035.030.0217

Chevenet, F., S. Doledec \& D. Chessel. 1994. A fuzzy coding approach for the analysis of long-term ecological data. Freshw. Biol. 31:295-309. https://doi.org/10.1111/j.1365-2427.1994.tb01742.x

Currie, D. \& G. Parry. 1999. Impacts and efficiency of scallop dredging on different soft substrates. Can. J. Fish. Aquat. Sci. 56:539-550. https://doi.org/10.1139/cjfas-56-4-539

Dolmer, P. 1998. Seasonal and spatial variability in growth of Mytilus edulis (L.) in a brackish sound: comparisons of individual mussel growth and growth of size classes. Fish. Res. 34:17-26. https://doi.org/10.1016/S0165-7836(97)00081-7

Dolmer, P. \& R. Frandsen. 2002. Evaluation of the Danish mussel fishery: suggestions for an ecosystem management approach. Helgol. Mar. Res. 56:13-20. https://doi.org/10.1007/s10152001-0095-6

Dolmer, P., T. Kristensen, M. L. Christiansen, M. F. Petersen, P. S. Kristensen \& E. Hoffmann. 2001. Short-term impact of blue mussel dredging (Mytilus edulis L.) on a benthic community. Hydrobiologia 465:115-127. https://doi.org/10.1023/A:1014549026157

Eigaard, O. R., F. Bastardie, M. Breen, G. E. Dinesen, N. T. Hintzen, P. Laffargue, L. O. Mortensen, J. R. Nielsen, H. C. Nilsson, F. G. O’Neill, H. Polet, D. G. Reid, A. Sala, M. Sköld, C. Smith, T. K. Sørensen, O. Tully, M. Zengin \& A. D. Rijnsdorp. 2016. Estimating seabed pressure from 
demersal trawls, seines, and dredges based on gear design and dimensions. ICES J. Mar. Sci. 73:i27-i43. https://doi.org/10.1093/icesjms/fsv099

Eigaard, O. R., F. Bastardie, N. T. Hintzen, L. Buhl-Mortensen, P. Buhl-Mortensen, R. Catarino, G. E. Dinesen, J. Egekvist, H. O. Fock, K. Geitner, H. D. Gerritsen, M. M. González, P. Jonsson, S. Kavadas, P. Laffargue, M. Lundy, G. Gonzalez-Mirelis, J. R. Nielsen, N. Papadopoulou, P. E. Posen, J. Pulcinella, T. Russo, A. Sala, C. Silva, C. J. Smith, B. Vanelslander \& A. D. Rijnsdorp. 2017. The footprint of bottom trawling in European waters: distribution, intensity, and seabed integrity. ICES J. Mar. Sci. 74:847-865. https://doi.org/10.1093/icesjms/fsw194

Ærtebjerg, G., J. H. Andersen \& O. S. Hansen. 2003. Nutrients and eutrophication in Danish marine waters: a challenge for science and management. National Environmental Research Institute, 126. Ministry of the Environment. Available at:

https://www.dmu.dk/1_viden/2_publikationer/3_Ovrige/rapporter/Nedmw2003_0-23.pdf

European Commission. 2020. EU Biodiversity Strategy for 2030. Brussels: 20.5.2020 COM (2020) 380

European Union. 1992. Habitats directive: Council Directive 92/43/EEC of 21 May 1992 on the conservation of natural habitats and of wild fauna and flora. Off. J. Eur. Union. L. 206:7-50

FAO. 2020. Fisheries and aquaculture information and statistics branch [Statistics Query Results]. Available at: http://www.fao.org/fishery/statistics

Frandsen, R. P., O. R. Eigaard, L. K. Poulsen, D. Tørring, B. Stage, D. Lisbjerg \& P. Dolmer. 2015. Reducing the impact of blue mussel (Mytilus edulis L.) dredging on the ecosystem in shallow water soft bottom areas. Aquat. Conserv. 25:162-173. https://doi.org/10.1002/aqc.2455

Foreign Ministry of Denmark. 2019. Målsætninger og forvaltningsprincipper for muslinge- og $\varnothing$ stersskrab og øvrig muslinge- og østers produktion i og udenfor Natura 2000 områder. Available at: https://fiskeristyrelsen.dk/media/10650/muslinge-og-oesterspolitik.pdf

Hall, S. J., D. Basford \& M. R. Robertson. 1990. The impact of hydraulic dredging for razor clams Ensis sp. (S.) on an infaunal community. Neth. J. Sea Res. 27:119-125. https://doi.org/10.1016/0077-7579(90)90040-N

Hall-Spencer, J. \& P. G. Moore. 2000. Scallop dredging has profound, long-term impacts on maerl habitats. ICES J. Mar. Sci. 57:1407-1415. https://doi.org/10.1006/jmsc.2000.0918

Hansen, J. W. 2012. Marine områder 2011. NOVANA. Videnskabelig rapport fra DCE-Nationalt Center for Miljø og Energi nr. 34. Available at: http://www.dmu.dk/Pub/SR34.pdf

Hoffmann, E. \& P. Dolmer. 2000. Effect of closed areas on distribution of fish and epibenthos. ICES J. Mar. Sci. 57:1310-1314. https://doi.org/10.1006/jmsc.2000.0921.

Hylleberg, J. 1993. Extinction and immigration of benthic fauna. The value of historical data from Limfjorden, Denmark. Ist. Sci. Ambientali. Mar. Santa-Margherita Ligure (Italy). 43-70. Available at: https://www.academia.edu/10220679

ICES. 2019. Working Group on Spatial Fisheries Data (WGSFD). ICES Sci. Rep. 1-52, doi: 10.17895/ices.pub.5648 
Josefson, A. B. \& J. L. S. Hansen. 2004. Species richness of benthic macrofauna in Danish estuaries and coastal areas. Glob. Ecol. Biogeogr. 13:273-288. https://doi.org/10.1111/j.1466822X.2004.00091.x.

de Juan, D., S. Thrush \& M. Demestre. 2007. Functional changes as indicators of trawling disturbance on a benthic community located in a fishing ground (NW Mediterranean Sea). Mar. Ecol. Prog. Ser. 334:117-129. https://doi.org/10.3354/meps334117

Kaiser, M., K. Clarke, H. Hinz, M. Austen, P. Somerfield \& I. Karakassis. 2006. Global analysis of response and recovery of benthic biota to fishing. Mar. Ecol. Prog. Ser. 311:1-14. https://doi.org/10.3354/meps311001

Kirkegaard, J. B. 1992a. Havbørsteorme I: errantia. Danmarks Fauna 83:1-416

Kirkegaard, J. B. 1992b. Havbørsteorme II: sedentaria. Danmarks Fauna 83:1-451

Lambert, G. I., L. G. Murray, J. G. Hiddink, H. Hinz, H. Lincoln, N. Hold, G. Cambiè \& M. J. Kaiser. 2017. Defining thresholds of sustainable impact on benthic communities in relation to fishing disturbance. Sci. Rep. 7:5440. https://doi.org/10.1038/s41598-017-04715-4

LeBlanc, S. N., H. P. Benoît \& H. L. Hunt. 2015. Broad-scale abundance changes are more prevalent than acute fishing impacts in an experimental study of scallop dredging intensity. Fish. Res. 161:8-20. https://doi.org/10.1016/j.fishres.2014.06.001

Lincoln, R. J. 1979. British Marine Amphipoda: Gammaridea. British Museum 818:1-658. (Natural History)

Macleod, C., N. Moltschaniwskyj \& C. Crawford. 2008. Ecological and functional changes associated with long-term recovery from organic enrichment. Mar. Ecol. Prog. Ser. 365:17-24. https://doi.org/10.3354/meps07534.

McLaverty, C., O. R. Eigaard, G. E. Dinesen, H. Gislason, A. Kokkalis, A. C. Erichsen \& J. K. Petersen. 2020. High-resolution fisheries data reveal effects of bivalve dredging on benthic communities in stressed coastal systems. Mar. Ecol. Prog. Ser. 642:21-38. https://doi.org/10.3354/meps13330

Miller, D. C., C. L. Muir \& O. A. Hauser. 2002. Detrimental effects of sedimentation on marine benthos: what can be learned from natural processes and rates? Ecol. Eng. 19:211-232. https://doi.org/10.1016/S0925-8574(02)00081-2

Nielsen, P., M. M. Nielsen, C. McLaverty, K. Kristensen, K. Geitner, J. Olsen, C. Saurel \& J. K. Petersen. 2021. Management of bivalve fisheries in marine protected areas. Mar. Policy 124:104357. https://doi.org/10.1016/j.marpol.2020.104357

Norling, P. \& N. Kautsky. 2007. Structural and functional effects of Mytilus edulis (L.) on diversity of associated species and ecosystem functioning. Mar. Ecol. Prog. Ser. 351:163-175. https://doi.org/10.3354/meps07033

O’Neill, F. G. \& A. Ivanović. 2016. The physical impact of towed demersal fishing gears on soft sediments. ICES J. Mar. Sci. 73:i5-i14. https://doi.org/10.1093/icesjms/fsv125 
Pastor, A., J. Larsen, C. Mohn, C. Saurel, J. K. Petersen \& M. Maar. 2020. Sediment transport model quantifies plume length and light conditions from mussel dredging. Front. Mar. Sci. 7:576530. https://doi.org/10.3389/fmars.2020.576530

Pearson, T. \& R. Rosenberg. 1978. Macrobenthic succession in relation to organic enrichment and pollution of the marine environment. Oceanogr. Mar. Biol. Annu. Rev. 16:229-311

Peterson, C. \& P. Jensen. 1911. Valuation of the sea: animal life of the sea-bottom, its food and quantity. Am. Nat. 47:378-384. https://doi.org/10.2983/035.034.0121u1.10

Qian, P. Y. \& F. S. Chia. 1994. In situ measurement of recruitment, mortality, growth, and fecundity of Capitella sp. (Annelida: Polychaeta). Mar. Ecol. Prog. Ser. 111:53-62

Ragnarsson, S. \& M. Lindegarth. 2009. Testing hypotheses about temporary and persistent effects of otter trawling on infauna: changes in diversity rather than abundance. Mar. Ecol. Prog. Ser. 385:51-64. https://doi.org/10.3354/meps08056

Rhoads, D. C. \& D. Young. 1970. The influence of deposit-feeding organisms on sediment stability and community structure. J. Mar. Res. 28:150-178

Rijnsdorp, A. D., F. Bastardie, S. G. Bolam, L. Buhl-Mortensen, O. R. Eigaard, K. G. Hamon, J. G. Hiddink, N. T. Hintzen, A. Ivanović, A. Kenny, P. Laffargue, J. R. Nielsen, F. G. O’Neill, G. J. Piet, H. Polet, A. Sala, C. Smith, P. D. van Denderen, T. van Kooten \& M. Zengin. 2016. Towards a framework for the quantitative assessment of trawling impact on the seabed and benthic ecosystem. ICES J. Mar. Sci. 73:i127-i138. https://doi.org/10.1093/icesjms/fsv207

Rumohr, H. \& P. Krost. 1991. Experimental evidence of damage to benthos by bottom trawling with special reference to Arctica islandica (L.). Meeresforschung. Rep. Mar. Res. 33:340-345

Sciberras, M., J. G. Hiddink, S. Jennings, C. L. Szostek, K. M. Hughes, B. Kneafsey, L. J. Clarke, N. Ellis, A. D. Rijnsdorp, R. A. McConnaughey, R. Hilborn, J. S. Collie, C. R. Pitcher, R. O. Amoroso, A. M. Parma, P. Suuronen \& M. J. Kaiser. 2018. Response of benthic fauna to experimental bottom fishing: a global meta-analysis. Fish Fish. 19:698-715. https://doi.org/10.1111/faf.12283

Sciberras, M., R. Parker, C. Powell, C. Robertson, S. Kröger, S. Bolam \& J. G. Hiddink. 2016. Impacts of bottom fishing on the sediment infaunal community and biogeochemistry of cohesive and non-cohesive sediments. Limnol. Oceanogr. 61:2076-2089. https://doi.org/10.1002/lno.10354

Stewart-Oaten, A. \& J. R. Bence. 2001. Temporal and spatial variation in environmental impact assessment. Ecol. Monogr. 71:305-339, doi: 10.1890/00129615(2001)071[0305:TASVIE]2.0.CO;2

Tebble, N. 1976. British bivalve seashells: a handbook for identification, 2nd edition, vol. 1. Royal Scottish Museum. 212 p

Thrush, S. F., J. E. Hewitt, V. J. Cummings \& P. K. Dayton. 1995. The impact of habitat disturbance by scallop dredging on marine benthic communities: what can be predicted from the results of experiments? Mar. Ecol. Prog. Ser. 129:141-150. https://doi.org/10.3354/meps 129141 
Thrush, S. F. \& P. K. Dayton. 2002. Disturbance to marine benthic habitats by trawling and dredging: implications for marine biodiversity. Ann. Rev. Ecol. Syst.

https://doi.org/10.1146/annurev.ecolsys.33.010802.150515

Tulp, I., S. Glorius, A. Rippen, D. Looije \& J. Craeymeersch. 2020. Dose-response relationship between shrimp trawl fishery and the macrobenthic fauna community in the coastal zone and Wadden Sea. J. Sea Res. 156:101829. https://doi.org/10.1016/j.seares.2019.101829

Underwood, A. J. 1992. Beyond BACI: the detection of environmental impacts on populations in the real, but variable, world. J. Exp. Mar. Biol. Ecol. 161:145-178. https://doi.org/10.1016/00220981(92)90094-Q

van Denderen, P., S. Bolam, J. Hiddink, S. Jennings, A. Kenny, A. Rijnsdorp \& T. van Kooten. 2015. Similar effects of bottom trawling and natural disturbance on composition and function of benthic communities across habitats. Mar. Ecol. Prog. Ser. 541:31-43. https://doi.org/10.3354/meps 11550

Wijsman, J. W. M., K. Troost, J. Fang \& A. Roncarati. 2019. Global production of marine bivalves. Trends and challenges. In: Goods and services of marine bivalves. Springer [Online]. pp. 7-26. https://doi.org/10.1007/978-3-319-96776-9

Ysebaert, T., M. Hart \& P. M. J. Herman. 2009. Impacts of bottom and suspended cultures of mussels Mytilus spp. (L.) on the surrounding sedimentary environment and macrobenthic biodiversity. Helgol. Mar. Res. 63:59-74. https://doi.org/10.1007/s10152-008-0136-5 